\title{
Forensic Expert Activity: Issues of Improving Effectiveness
}

\author{
Inessa Ovsiannykova \\ ORCID: 0000-0002-3351-7781 \\ National Scientific Center "Hon. Prof. M. S. Bokarius \\ Forensic Science Institute”, Ukraine \\ inessa_ovs@ukr.net
}

\begin{abstract}
Improving efficiency of forensic science nowadays is poorly understood and extremely relevant for administration of effective justice in Ukraine. To understand the goals that need to be achieved to obtain the desired result, first the existing problems that need to be addressed must be understood. Based on the previous analysis of the administrative legislation of Ukraine, scientific literature, as well as the practical experience of experts, the article considers the key problems in the field of forensic examination of theoretical, methodological, practical and administrative nature, which must be addressed to improve judicial efficiency in the country.
\end{abstract}

Keywords: effectiveness, expert, forensic expert activity.

\section{Introduction}

In modern conditions of formation of Ukraine as a state governed by the rule of law, the role and importance of legal regulation of public relations becomes especially relevant. Thus, the main feature of the model of the state, which is characterised as legal, is precisely the feature of high legal regulation of social relations. Modern society, first, puts forward a person and citizen with their needs focussing on effective justice. The judiciary is endowed with certain powers, without which functioning of the rule of law is impossible, development of social relations in the vector of balance is unattainable, and the level of justice for everyone is utopian. That is why every civilized country, aiming to provide proper justice quickly and efficiently, is obliged to organise a system of justice in which all efforts and resources invested in the judiciary will be effective, rational and sufficient (Shcherbliuk, 2021). In Ukraine, guaranteeing rights to a fair trial and ensuring 
the rule of law is impossible without development of effective system of forensic science support of justice providing not only to implement steps on modernisation of the current legislation but the need for systemic transformations in the field of forensic expert activity, in particular. The aim of the research is to consider some of the main problems of theoretical, methodological, practical and administrative nature that prevent forensic activities to be an effective part of the system of expert support of justice in Ukraine and need to be addressed urgently.

\section{Discussion and Results}

Forensic science plays an important role in administration of justice and assistance to stakeholders, so development and improvement of judicial reform that is taking place in Ukraine today is impossible without some effective changes in the field of forensic science. Nevertheless, such changes, especially administrative and legal changes in the legislation governing forensic expert activity, are not always clear and effective, which causes a number of problems, which, in turn, are the cause of debate among scholars and lawmakers.

Starting to consider the issue of increasing efficiency of forensic expert activity, it is necessary to determine what such forensic activity is. The very concept of "activity" is the subject of research in a large number of scientific areas. It is usually associated with two categories of purpose (purposefulness) and result (performance).

In addition, Article 7 of the Law of Ukraine On Judicial Examination provides that forensic activities in Ukraine are carried out by state specialised institutions and their territorial branches, expert institutions of communal ownership, as well as forensic experts who are not employees of these institutions and other specialists (experts) from the relevant fields of knowledge. State specialised institutions include:

1) research institutions of forensic examinations of the Ministry of Justice of Ukraine;

2) research institutions of forensic examinations, forensic medical and forensic psychiatric institutions of the Ministry of Health of Ukraine;

3) expert services of the Ministry of Internal Affairs of Ukraine, the Ministry of Defense of Ukraine, the Security Service of Ukraine and the State Border Guard Service of Ukraine (Zakon Ukrainy, 25.02.1994).

The legislator clearly stipulates that forensic activities related to forensic and forensic psychiatric examinations are carried out exclusively by state specialised institutions.

From a scientific point of view, different scholars give different definitions of "activity", "expert activity", "forensic activity", and therefore there is a problem of their different interpretations and lack of solid theoretical basis for this, which, in turn, causes problems in the activities of law enforcement agencies that carry out legal proceedings, on the types, forms of expert activity, tasks to be solved and other relevant issues. 
Dzhavadov (2000) reveals understanding of forensic activity as a separate type of legal activity, which has features inherent in it as a specific type of human activity. Among the features of this activity, he refers to its legal nature and a separate entity, which may be a forensic expert. Zherebko (2019) adheres to the opinion that forensic activity should be understood as the performance by a specific person of the functions assigned to him by law to ensure justice. According to Strilets (2009), forensic activity is a statutory activity of forensic institutions, aimed at conducting independent forensic examinations as a result of objective, complete and comprehensive research in compliance with modern advances in science and technology, organisation of forensic institutions as a whole and their structural subdivisions, their scientific-methodical and information support, selection and training of forensic experts. Averyanova et al. argue that forensic activity is a system of actions and related legal relations carried out in the process of judicial proceedings by authorised bodies and persons on the appointment, organisation and conduct of forensic examinations (Averyanova et al., 2008). Segai (2003) defines forensic activity as the activity of the state, legal entities and individuals to ensure justice by an independent, objective and qualified examination carried out by professional (certified) forensic experts.

Analysis of scientific opinions shows that at present in modern science and practice there is no clear and comprehensive definition of "forensic activity", so today forensic activity in connection with changes in public life, requires a theoretical understanding of its concept, essence, tasks, definition of directions of development and improvement (Chornous \& Lopata, 2016).

Based on the above, it can be stated that the scientific community has formed an opinion about forensic activity as a complex phenomenon, which includes, along with expert research, other elements, primarily of organisational, methodological and didactic nature. Meanwhile, the activity itself is mainly analysed from the point of view of the characteristics of the expert's personality, its professional, social and psychological aspects. It is logical that within the framework of this approach, a forensic expert is primarily called a forensic expert as a bearer of special knowledge and as a procedural person as a subject of forensic activity. The question of other subjects finds much less coverage in the scientific literature. This mainly applies to a forensic institution or organisation (Smirnova, 2012).

Some scholars rightly point out in their works that forensic activity is extremely important in every democratic state and should be carried out effectively, and its administrative and legal regulation should take place without violating human rights and freedoms (Oliinyk, 2013; Rusetskyi, 2017; Skoryk \& Biriukov, 2020).

In order to determine the effectiveness of an activity, you must first define the concept of "effect". According to the dictionary definition, "effect" (Latin effectus - performance, action, from efficio - action, perform) - the result, the consequence of any causes, measures, actions; "effectiveness" - the result, a consequence of any causes, forces, actions (Melnychuk, 1987). 
Scientists in various fields of science have repeatedly tried to define the concept of "effect". For example, in the article of Sinicyna (2004), the effect is considered as a result, a consequence of any causes, actions, economic measures (introduction of new equipment and investment projects, commercial agreements, implementation of any economic decisions, etc.). According to Petrova, the effect is a useful result, expressed in terms of valuation (Yachmenova et al., 2010). Surmin formulates the definition of "effect" as a result, a consequence of any action (Rats, 2008). Zagorodniy et al. (2002) reveals the concept of "effect" as an achieved result in a certain form - material, monetary, social and economic. Based on the above, there is a common scientific opinion that the "effect" is the result that arises as a result of certain actions. Thus, understanding of the term "effectiveness" is related to actions that lead to the desired consequences; thus, the concept of "effectiveness" is synonymous with the concept of "active". It follows that "effectiveness" is efficiency, result, consequence of certain causes, forces, actions. Nevertheless, effectiveness is not just the ability of someone or something to act in such a way as to achieve the intended consequences. This is a rather complex phenomenon, determined by the ratio of human, organisational, time, scientific and technical, material resources and the results obtained (Tsvietkov, 1998).

Issues of increasing effectiveness of forensic expert activity have always been the most important, since work results of forensic experts using specific expertise, the most effective methods and high-tech scientific and technical means in many ways determine efficiency of law enforcement agencies to fight against crime allowing to realize scientific and technical potential of society while implementing justice and providing a new impulse for the development of the state and strength in law enforcement (Svintsytskyi, 2020). Proclamation of independence, change of economic conditions of management of economy, ideology of the development of market relations in Ukraine, formation of a civil society - all this sets new challenges for the authorities regarding public administration in the field of forensic expert activity. Thus, nowadays, there is an urgent need for new mechanisms of forensic expert activity, which would ensure its scientific nature and at the same time create conditions for improving its economic and social effectiveness.

Issues of efficient justice and forensic expert activity become objects of scientific research and subject of various thematic discussions that confirms relevance of the problem. Forensic expert activity is one of the areas where reforms are much desired (Filipenko, 2020).

For example, on February 6-7, 2020, on the basis of the National Scientific Centre "Hon. Prof. M. S. Bokarius Forensic Science Institute" together with the Department of Criminalistics of Yaroslav Mudryi National Law University, a round table meeting on Problems of Reforming the Basic Legislation of Ukraine on Forensic Science Support of Justice was held in Kharkiv, which was the first organised event scientists of higher education institutions, academic institutions, scientists and those with significant practical experience working in forensic scientific institutions of Ukraine, representatives of public 
organisations of forensic expertise attended. The purpose of this meeting was to discuss about the issues related to forensic science support of justice in Ukraine in general and forensic expert activity, in particular.

Analysis of round table content, studying dissertation and other research papers on this topic indicates common scientific opinions on importance of reforming forensic expert activity and the need to make legislative changes to its regulation and efficient judicial reform in Ukraine. In other words, it means development of the concept of forensic science in Ukraine that should be understood as systematic statement of goals and priority directions of its development which should be based on democratic judicial principles and on challenges that are in connection with the European vector development. Lack of balanced opinions leads to chaotic lawmaking, and uncertainty of some positions reduces effectiveness of using the specific expertise in the field (Yaroslav, 2020).

Consequently, it can be argued that efficacy of administrative and legal regulation of forensic expert activity in a wider sense should be considered as a result of purposeful and systematic activity of public administration bodies aimed at performing tasks and functions of the state in the field of forensic science (Ovsiannykova, 2019). However, it should be noted that Law of Ukraine On Judicial Examination that is in force now does not contain norms that would directly identify common goals and tasks of forensic expert activity and its subjects.

One of the main goals that should be applied to Ukraine on its way approaching the European Community standards should be improvement of administrative and legal regulation of Forensic Science Institution in Ukraine and eliminating certain gaps in the current law which the expert activity is regulated by.

Importance of changes that need to be made in the areas of legal policy to ensure human and civil rights and freedoms is discussed in the Decree of the President of Ukraine on urgent measures to reform and strengthen the state (Ukaz Prezydenta Ukrainy, 08.11.2019). The decree states the importance of drafting laws and amending some legislative acts of Ukraine related to forensic expert activity. This means that statesman recognises that at present the administrative and legal regulation of forensic expert activity is ineffective and requires improvement.

Nonetheless, optimisation of legal support of forensic expert activity and determination of increase directions of its effectiveness, first of all, provides the definition and features of forensic institution activity that is in need of accurate definition and general purpose characteristics, tasks and functions of their activities reflecting their importance and place in the system of relations with other subjects of legal relations in the field of forensic expert activity and form the basis of their legal status (Ostropilets, 2019).

It should also be noted that the judicial reform carried out in Ukraine, development of a market economy, global and regional integration processes have led to the presentation of higher requirements by the participants in legal proceedings to the quality of forensic examinations and their scientific, methodological, organisational and technical support. 
Aminev and Abdullin, forensic experts, address the problem of the quality of forensic examinations in conditions of improving judicial proceedings. The professors note the need to increase the level of methodological support of forensic expert researches through international cooperation of forensic institutions for creation of an objective evidence-based justice system. In their opinion, central role in international cooperation in the field of forensic science should be taken by the integration of methodological expert research foundations that consist of merging the domestic theoretical base of forensic expertology with foreign applied expert school. Thus, cooperation of forensic expert schools in different countries can lead to mutual enrichment due to the possible integration of two radically different conceptual approaches to the forensic expert activity methodology (Aminev \& Abdullin, 2020). Importance of this problem is evidenced by the results of a survey conducted by Nguen Van Kau among law enforcement officers of the Socialist Republic of Vietnam; majority of the respondents $(83.27 \%)$ stated that one of the main ways to improve effectiveness of new species of forensic examinations is international cooperation with other countries (Nguen Van Kau, 2020).

Recently, the role of international cooperation in the field of forensic science has been steadily growing. The main purpose of state forensic institutions is to protect interests of the state, rights and freedoms of citizens and rights of legal entities by conducting objective, scientifically sound forensic examination and expert research. International cooperation of forensic institutions is important for implementation of the rule of law improving forensic activities and forensic science quality as one of the main forms of using specific expertise in modern justice, as well as formation of preventive recommendations for law enforcement agencies. Intensified activity in the field of international integration of the country into the world legal space sets the state forensic institutions a wide range of tasks to establish such international cooperation and expand cooperation with foreign specialised forensic science institutions (Filipenko et al., 2021).

In modern administrative-legal science and practice of forensic expert activity, a number of approaches are distinguished regarding possible forms of implementation of international cooperation. In accordance with the strategy approved by the Decree of the President of Ukraine, to increase the efficiency of the judiciary and institutions of justice, as well as to strengthen public confidence in them, the basic principles and directions for further sustainable functioning and development of the justice system in the country should be implemented considering the best international standards and practices (Ukaz Prezydenta Ukrainy, 11.06.2021).

According to the Strategic Business Plan, tasks of developing international standards include:

1) enhancement of reliability of forensic evidence;

2) establishment of consistent work practices that facilitate forensic laboratories / agencies from different jurisdictions to work collaboratively in response to cross border investigations;

3) enabling of agencies from different jurisdictions to support one another in case of a catastrophic event that exhausts a jurisdiction's capabilities; 
4) allowing for the exchange of forensic results, information and intelligence including sharing of databases;

5) ensuring forensic supplies are fit for purpose and do not impact upon the features under examination;

6) allowing mobility of forensic professionals (ISO/TC 272 Forensic sciences / Strategic business plan, 2016).

Considering expansion of scientific and methodological base as one of the leading areas of international cooperation in the field of forensic examination includes:

1) development of a detailed modern practical guide to forensic disciplines;

2) exchange of information from databases for expert analysis (in particular, regarding weapons and ammunition, explosives, drugs, etc.);

3) development and implementation of testing for aptitude and ability to cooperate in the field of expert activities;

4) increasing the level of information content about forensic examination and appropriate training for representatives of law enforcement agencies and the judiciary;

5) stimulating the exchange of data for expert analysis and improving the quality of exchange;

6) increasing the competence of forensic experts, etc. (Simakova-Yefremian, 2017).

Thus, international cooperation in the field of forensic expertise, harmonisation of expert national legislation and development of relevant national standards, as well as various forms of exchange of information and best practices in the field of theory and practice of forensic expertise, expansion of scientific and methodological base in the area are important factors affecting effectiveness of forensic expertise.

Legislation and law enforcement in modern conditions present more and more complex criteria for objectification of forensic examination, where the cost of error these days has increased significantly. Participants in legal proceedings are aware of typical mistakes that are often encountered in production of forensic examinations by both state and non-state forensic experts, namely: the expert goes beyond their competence (mainly by solving legal issues), procedural violations, professional incompetence, etc. Therefore, another important component of the problem of forensic effectiveness is related to experts themselves. According to the Law of Ukraine On Judicial Examination that is in force now, forensic expert activity is carried out on the principles of research legality, independence, objectivity and completeness (Zakon Ukrainy, 25.02.1994). Therefore, it is indisputable that expert conclusion should reflect all those principles. Regardless of the fact that forensic expert conclusion correctness is guaranteed by the said law, there are scientific thoughts on mistakes that influence effectiveness of forensic expert activity, that are:

1) objective errors - those that do not depend on forensic expert activities;

2) subjective errors - those that depend on forensic expert activities and their way of thinking. 
Prus (2014) defines error as the result of deceptive action (inaction) detected during the activities performed by law enforcement subjects with adoption of incorrect or erroneous decisions. According to Platonov (1972), a psychologist, error is the result of a wrong action that has not achieved its goal. In general, the problem of errors is an important independent research area that is justifiably paid attention to by many scientists in various knowledge fields.

Forensic expert error in general as defined by Belkin (1997) is the judgment of the expert, which does not correspond to objective reality or their actions that do not lead to the purpose of forensic research, in case when both the distorted judgment and incorrect actions are the result of good faith deception. Klimenko (1988) also speaks of forensic expert error as a result of good faith deception while allowing possibility of conscious error on the expert part.

Predetermined willful erroneous forensic expert conclusion can be expressed in conscious disregard or silencing while making the research of essential facts and characteristics of forensic examination objects; distorted description of the facts and signs predetermines their wrong assessment or predetermined wrong actions and operations on their research, it can also be expressed in predetermined wrong choice of forensic expert methods or their application. Predetermined willful forensic expert conclusion falsity can be determined only by the court while studying the entire set of evidence collected in case of availability of all crime signs (Kiyan, 2012).

Wrong forensic expert conclusion as a result of false or fake primary source information previously presented to them for research can be attributed to subjective factors. In this regard, Bululukov (2015) rightly notes that criminal investigator error that they have caused in making a tactical decision on forensic examination assignment is transformed into an expert error only for reasons of subjective nature.

Zavdovieva et al. (2018) also remarks on availability of unreliable and probable information in materials submitted for research, which require increased forensic expert attention (in particular at the stage of preliminary research) that is connected with assessment of information reliability, establishment of obviously unreliable information and verification of probable information. The authors of the current study suggest that in such circumstances there can be no question of forensic expert error, because the cause of forensic expert error is corresponding erroneous or intentional actions of the legal agency that appointed the examination.

\section{Conclusions}

During the stage of transformation process, a number of methodological, practical and administrative problematic issues take place in forensic expert activity and require their effective solution. The authors of the present study are of opinion that all these issues should be considered through the prism of effectiveness of achieving the goals and objectives defined for forensic experts, forensic institutions and the state as a whole. 


\section{Bibliography}

\section{Legal acts}

1. ISO/TC 272 Forensic sciences. Strategic business plan. (16.01.2016). https://isotc.iso. org/livelink/livelink/fetch/2000/2122/687806/ISO_TC_272_Forensic_Sciences_. pdf? nodeid=18832591\&vernum=2. (in English)

2. Ukaz Prezydenta Ukrainy, 11.06.2021, No. 231/2021: Stratehiia rozvytku systemy pravosuddia ta konstytutsiinoho sudochynstva na 2021-2023 roky. https://zakon.rada.gov.ua/laws/ show/231/2021\#Text. (in Ukrainian)

3. Ukaz Prezydenta Ukrainy, 08.11.2019, No. 837/2019: Pro nevidkladni zakhody z provedennia reform ta zmitsnennia derzhavy. https://zakon.rada.gov.ua/laws/show/837/2019\#Text. (in Ukrainian)

4. Zakon Ukrainy 25.02.1994: Pro sudovu ekspertyzu, No. 4038 - XII. https://zakon.rada.gov.ua/ laws/show/4038-12\#Text. (in Ukrainian)

\section{Literature}

5. Aminev, F. G. \& Abdullin, R. R. (2020). O tselesoobraznosti integratsii metodologicheskih osnov ekspertnyih issledovaniy v hode mejdunarodnogo sotrudnichestva sudebno-ekspertnyih organizatsiy. Sudebnaya ekspertiza = Forensic examination, 4(64), 8-18. http://www.va-mvd.ru/ sudek/archive/64.pdf. (in Russian)

6. Averyanova, T. V. et al. (2008). Kriminalistika: ucheb. dlya vuzov. 3-e izd., pererab. i dop. Moskva: Norma, 992 p. (in Russian)

7. Belkin, R. S. (1997). Kurs kriminalistiki: Chastnyie kriminalisticheskie teorii, 3 vols. Moskva: Yuristy. (in Russian)

8. Bululukov, O. Yu. (2015). Innovative approach in research of errors at setting judicial examinations. Law and Innovations. No. 3, 139-144. http://www.irbis-nbuv.gov.ua/cgi-bin/irbis_nbuv/ cgiirbis_64.exe?I21DBN=LINK\&P21DBN=UJRN\&Z21ID =\&S21REF=10\&S21CNR=20\&S21 STN=1\&S21FMT=ASP_meta\&C21COM=S\&2_S21P03=FILA=\&2_S21STR=apir_2015_3_21 (in Ukrainian)

9. Chornous, Y. M. \& Lopata, O. A. (2016). Poniattia ta zavdannia sudovo-ekspertnoi diialnosti u suchasnykh realiiakh. Kryminalistyka i sudova ekspertyza. Vol. 61, 3-12 (in Ukrainian).

10. Dzhavadov, F. M. (2000). Kontseptualni osnovy rozvytku sudovoi ekspertyzy v suchasnykh umovakh. (Extended abstract of Doctoral thesis). Kyiv. (in Ukrainian)

11. Filipenko, N. Ye. (2020). Perspektyvy rozvytku ekspertnykh ustanov Ukrainy z ohliadu na zakonodavchi zminy shchodo pytan ekspertnoho zabezpechennia pravosuddia. Problemy reformuvannia bazovoho zakonodavstva Ukrainy z pytan ekspertnoho zabezpechennia pravosuddia. Kharkiv: KhNDISE, pp.94-96. (in Ukrainian)

12. Filipenko, N. et al. (2021). Implementation of Preventive Activity: Foreign Experience in Criminological Work of Forensic Science Institutions. Electronic Scientific Journal of Law “Socrates”, 1(19), 32-39. https://doi.org/10.25143/socr.19.2020.1.032-038.

13. Kiyan, T. M. (2012). Aktualnyie prichinyi vozniknoveniya ekspertnyih oshibok. Liudyna, suspilstvo, derzhava: publichno-pravovyi aspect. VIII Prybuzki yurydychni chytannia. Mykolaiv: Ilion, pp.159-160. http://dspace.onua.edu.ua/handle/11300/3803. (in Russian)

14. Klimenko, N. I. (1988). Ekspertnyie oshibki i ih prichinyi. Kriminalistika i sud ekspertiza. 1988. Vol. 37, 35-38. (in Russian) 
15. Melnychuk, O. S. (1987). Slovnyk inshomovnykh sliv. Kyiv: Holovna redaktsiia Ukrainskoi radianskoi entsyklopedii Akademii nauk Ukrainskoi RSR. (in Ukrainian)

16. Nguen Van Kau. (2020). Pravovoe i informatsionnoe obespechenie sudebnoekspertnoy deyatelnosti v Sotsialisticheskoy Respublike Vetnam. (Diser. kand. yur. nauk). Moskva. (in Russian)

17. Oliinyk, O. O. (2013). Zarubizhnyi dosvid administratyvno-pravovoho rehuliuvannia sudovoekspertnoi diialnosti. Mytna sprava, 4(88), 270-274. (in Ukrainian)

18. Ostropilets, A. V. (2019). Zavdannia ta funktsii sudovo-ekspertnykh ustanov Ukrainy. Yevropeiski Perspektyvy = European Perspectives. № 2, 52-57. http://ep.unesco-socio.in.ua/archive/2019-2/. (in Ukrainian)

19. Ovsiannykova, I. M. (2019). Main approaches to determining the effectiveness of forensic expert activity: administrative and legal aspects. Theory and Practice of Forensic Science and Criminalistics. 20(2), 215-229. https://khrife-journal.org/index.php/journal/article/view/325. (in Ukrainian)

20. Platonov, K. K. (1972). O sisteme psihologii. Moskva: Myisl, 216. (in Russian)

21. Prus, E. U. (2014). Pomylka pry zastosuvanni prava. Poniattia ta kharakterystyka. Aktualni problemy polityky. Vol. 51, 79-86. http://dspace.onua.edu.ua/handle/11300/306. (in Ukrainian)

22. Rats, O. M. (2008). Vyznachennia sutnosti poniattia "efektyvnist funktsionuvannia pidpryiemstva". Ekonomichnyi prostir. Vol. 15, 275-285.

23. Rusetskyi, A. A. (2017). Pro orhanizatsiiu sudovo-ekspertnoi diialnosti: mizhnarodnyi aspekt. Teoriia ta praktyka sudovoi ekspertyzy i kryminalistyky. Vol. 17, 158-164. (in Ukrainian)

24. Segai, M. Y. (2003). Sudebnaya ehkspertologiya: ob»ekt, predmet, priroda i sistema nauki. Teoriia ta praktyka sudovoi ekspertyzy i kryminalistyky. Vol. 3, 25-32. (in Russian)

25. Shcherbliuk, O. V. (2021). Orhanizatsiini osnovy sudoustroiu v Ukraini. (Extended abstract of candidates thesis). Kyiv. (in Ukrainian)

26. Simakova-Yefremian, E. B. (2017). Teoretyko-pravovi ta metodolohichni zasady kompleksnykh sudovo-ekspertnykh doslidzhen. (Diser. kand. yur. nauk). Kharkiv (in Ukrainian)

27. Sinicyna, T. A. (2004). Ocenka ehffektivnosti sistemy upravleniya promyshlennym predpriyatiem - celevoj pokhod (Diser. kand. ehkon. nauk). Odessa. (in Ukrainian)

28. Skoryk, A. L. \& Biriukov, M. A. (2020). Poniattia ta sutnist kryminalistychnoi ekspertyzy. Teoriia ta praktyka sudovoi ekspertyzy i kryminalistyky. III Vseukr. nauk.-prak. konf. Kyiv-Mariupol: KUP NAN Ukrainy DonDUU, pp.269-271. (in Ukrainian)

29. Smirnova, S. A. (2012). Sudebnaya ekspertiza: perezagruzka (mul'timodal'noe izdanie) v trekh chastyah, 1 chast'. Moskva: RFCSE. (in Russian)

30. Strilets, H. O. (2009). Henezys systemy sudovo-ekspertnykh ustanov v Ukraini ta napriamky yikh diialnosti. [Extended abstract of Ph.D. candidates thesis]. Kyiv. (in Ukrainian)

31. Svintsytskyi, A. V. (2020). Systema ekspertnoho zabezpechennia pravosuddia v Ukraini na suchasnomu etapi: orhanizatsiino-pravovi aspekty. Problemy reformuvannia bazovoho zakonodavstva Ukrainy z pytan ekspertnoho zabezpechennia pravosuddia. Kharkiv: KhNDISE, pp.16-20. (in Ukrainian)

32. Tsvietkov, V. V. (1998). Pidvyshchennia efektyvnosti derzhavnoho upravlinnia - vazhlyva meta yoho reformuvannia. Reformuvannia derzhavnoho upravlinnia v Ukraini: problemy i perspektyvy, pp. 128-153.

33. Zavdovieva, I. H. et al. (2018). An error and its value in the forensic expert activity. Kryminalistychnyi visnik. 30(2), 31-39. https://visnyk.dndekc.mvs.gov.ua/index.php/visnuk/ article/view/30. (in Ukrainian) 
34. Zherebko, O. I. (2019). Sutnist y zmist sudovo-ekspertnoi diialnosti: vitchyznianyi dosvid. Teoriia ta praktyka sudovoekspertnoi diialnosti. VIII Mizhvidom. konf. Kyiv: MVS Ukrainy, NAVS Navch.-Nauk. instytut № 2, pp.150-154. (in Ukrainian)

35. Yachmenova, V. M., Vysochyna, M. V., \& Sulyma, O. Y. (2010). Efektyvnist upravlinnia diialnistiu promyslovoho pidpryiemstva ta diahnostyka zahroz: monohrafiia. Simferopol: VD ARIAL, p.472. (in Ukrainian)

36. Yaroslav, Yu. Yu. (2020). Do pytannia kontseptsii sudovoi ekspertyzy v Ukraini. Problemy reformuvannia bazovoho zakonodavstva Ukrainy z pytan ekspertnoho zabezpechennia pravosuddia. Kharkiv: KhNDISE, pp.109-117. (in Ukrainian) 